\title{
Effect of Date and Quantity of Potassium Fertilizer Application on Growth, Yield and Oil Quality of Sunflower Helianthus annuus L. var. flame
}

\author{
Faisal, M. Al -Taher ${ }^{1}$, Yahya, K. Jellab ${ }^{1,}$ Saad, A. M. Al-badry ${ }^{2}$ \\ 1 Field crop Department, College of Agriculture/ University of Al-Muthanna \\ 2 Field crop Department, College of Agriculture/ University of Thi-qar
}

\begin{abstract}
A field experiment was carried out in Thi-qar province - Batha city with two Seasons, $1^{\text {st }}$ experiment was during Fall season (2011) and $2^{\text {nd }}$ experiment was during Spring Season (2012) using R.C.B.Desgn. with three replications. The main objective of experiment was to find the effect of dates and levels of Potassium on oil quality and yield of Sunflower. Six levels of K were used ( $K_{0}=$ Control, $K_{1}=120 \mathrm{kgK}$. ha ${ }^{-1}($ Soil) $), K_{2}=6000 \mathrm{mgk.L^{- }}$

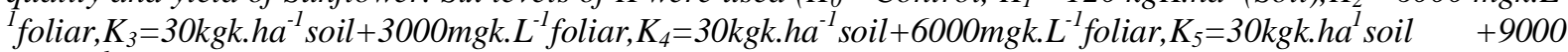
$m g k . L^{-1}$ foliar) and three dates $\left(T_{1}=8\right.$ leaves, $T_{2}=14$ leaves, $T_{3}=20$ leaves). The results showed that increasing of Potassium levels significantly caused increasing in (seed number, 1000 seed weight and yield plant) Fall and Spring seasons. The highest seed yield was $28,7 \%$ and it obtained by third date of $2^{\text {nd }}$ season. Also the percent of oil and oil yield of $1^{\text {st }}$ and $2^{\text {nd }}$ season were increased respectively. The interaction had significant effect on yield traits (seed number and seed 1000 weight) of $2^{\text {nd }}$ season. There was no effect for fertilization and dates in oleic acid for both seasons, while the linoleic acid was influenced by $1^{\text {st }}$ date of $1^{\text {st }}$ and $2^{\text {nd }}$ season respectively
\end{abstract}

Key words-Sunflower seed yield. Potassium application. Application date. Application quantity. Oil quality.

\section{Introduction}

Sunflower (Helianthus annuus L.) is an important oil seed crop in the world and it belongs to the family Asteraceae. It increased in last years as a result of the decreasing in the quantity of produced oils because of using it in many fields of life. In addition, the seeds contain high percentage of protein ranging from 20-30\%, and it used in poultry feed as well [1], Also the seeds contain high percent of oil reach to 50\% [2]. Sunflower oil characterizes with low saturated fatty acids that have essential role in arteries intransigence and high content of E vitamin [3]. The productivity of any crop is mainly based on several factors in which the agricultural practices come in at first, including the quantity and date of fertilizers application which consider important matters that can enable the crop to exploitation of different environmental factors (light, water, soil, etc.) with best way and increase the quantity and quality of yield per area, so many researchers have turned to use various means to increase the production by means of adding the micro and macro elements, particularly the potassium element, which plays an important role in increase and improve the quality of yield [4] . The researcher of Iraqi cropping systems notice careless of using potassium fertilizers for long time due to popular misconception that Iraqi soils are rich with potassium element, however fact this element exposes to fixation process in the primary and secondary clay minerals which change it from soluble or exchangeable form to slowly available in the soil solution [5].

Practically plant can't grow and develop normally with out of potassium element, so it can contributes in many important physiological processes in plant for instances, regulation of osmotic pressure of plant cells and it can controls the process of opening and closing of stomates. It also has a relationship to synthesis of protein and fats, synthesis of chlorophyll, stimulation of adenosine triphosphate (ATP) formation and photosynthesis, anabolism and metabolism of carbohydrates, translocation of photosynthetic. In addition potassium used to increase of lipids synthesis in oil crops. It also can contribute in action of approximately 60 enzymes [7].

So as showed above and on the basis of benefits of this crop as well as the positive effect of fertilization to increasing the yield per area with improving its quality, besides the scarcity of researches especially about potassium fertilization in Iraq, so this study was carried out in order to determination of best concentration of fertilizer for obtaining best productivity and quality per area and best time for potassium application.

\section{Materials and methods}

The field experiment was carried out during two seasons fall (2011) and spring (2012) at Batha district to study the effect of date and quantity of potassium fertilizer application on growth, yield and oil quality of Sunflower. The experiment was laid out in a Random Complete Block Design (R.C.B.D) with three replications. 
Soil samples were taken randomly from different locations for the entire experiment a study area in both seasons within layer $(0-30) \mathrm{cm}$. It had dried, crushed and sieved with sieve has mesh with $(2 \mathrm{~mm})$ diameter then mixed together. A complex sample was taken for each season. Physical and Chemical tests were done pre-cultivation including electrical conductivity (EC) and soil $\mathrm{pH}$ ) according to [8], soil texture and available potassium as it revealed in Table (1).

Table (1) Mechanical and Chemical Analysis during Fall and Spring seasons 2011 - 2012

\begin{tabular}{|c|c|c|c|c|}
\hline Soil Analysis & \multicolumn{2}{|c|}{ Fall Season } & \multicolumn{2}{|c|}{ Spring Season } \\
\hline pH & \multicolumn{2}{|c|}{8.3} & \multicolumn{2}{|c|}{7.9} \\
\hline Ec ms/cm ${ }^{-1}$ & \multicolumn{2}{|c|}{3.6} & \multicolumn{2}{|c|}{3.9} \\
\hline Soil texture & \multicolumn{2}{|c|}{ Clay } & \multicolumn{2}{|c|}{ Clay } \\
\hline Available K (PPm) & $\begin{array}{c}\text { Pre - } \\
\text { Cultivation }\end{array}$ & $\begin{array}{c}\text { Post - } \\
\text { Cultivation }\end{array}$ & $\begin{array}{c}\text { Pre - } \\
\text { Cultivation }\end{array}$ & $\begin{array}{c}\text { Post - } \\
\text { Cultivation }\end{array}$ \\
\hline & 165 & 155 & 167 & 156 \\
\hline
\end{tabular}

The researched factors in the experiment were six levels of potassium and three dates of application:

\section{A. Potassium levels:}

$\mathrm{K}_{0}$ : control.

$\mathrm{K}_{1}: 120 \mathrm{~kg} \mathrm{~K} \cdot \mathrm{ha}^{-1}$ soil.

$\mathrm{K}_{2}: 6000 \mathrm{mg} \mathrm{K} . \mathrm{L}^{-1}$ Foliar spray.

$\mathrm{K}_{3}: 30 \mathrm{~kg} \mathrm{~K} . \mathrm{ha}^{-1}$ soil $+3000 \mathrm{mg} \mathrm{K} . \mathrm{L}^{-1}$ Foliar spray.

$\mathrm{K}_{4}: 30 \mathrm{~kg} \mathrm{~K} \cdot \mathrm{ha}^{-1}$ soil $+6000 \mathrm{mg} \mathrm{K} \cdot \mathrm{L}^{-1}$ Foliar spray.

$\mathrm{K}_{5}: 30 \mathrm{~kg} \mathrm{~K} \cdot \mathrm{ha}^{-1}$ soil $+9000 \mathrm{mg} \mathrm{K} \cdot \mathrm{L}^{-1}$ Foliar spray.

\section{B. Dates of application:}

$\mathrm{T} 1=8$ true leaves.

$\mathrm{T} 2=14$ true leaves.

$\mathrm{T} 3=20$ true leaves.

The researched attributes were (number of seeds, 1000 seeds weight, seed yield of plant, Total seed yield, oil percent and Oil yield). All data were analyzed statically using (R.C.B.D.) and the means compared with (R.L.S.D.) at $(\mathrm{P} \leq 0.05)$ using (Gen stat v.10.3) software.

\section{Fall season}

\section{Results and discussion}

\subsection{Seed Number $\left(\right.$ seed.head $^{-1}$ )}

The data presented in table (2) indicated that potassium application significantly affected the seed number. head ${ }^{-1}$. Maximum seed number (861) seed.head ${ }^{-1}$ was observed on plants that treated with $\left(\mathrm{K}_{1}\right)$ treatment, whereas minimum value (589) seed.head ${ }^{-1}$ was observed on plants that treated with control $\left(\mathrm{K}_{0}\right)$ treatment. K3 and K5 treatments had non-significant effect on this trait between them. Our results is in agreement with [9] May be due to the role of fertilization, environmental conditions and variety during formation stage and completion of flowering buds, so the seed number was increased significantly.

Also with respect to fertilization dates had significant effect on seed number. The Second date $\left(\mathrm{T}_{2}\right)$ gave maximum seed number (867) seed.head ${ }^{-1}$, whereas minimum value (636) seed.head ${ }^{-1}$ was recorded at First date $\left(\mathrm{T}_{1}\right)$ due to potassium and other elements are existing in sufficient quantities during seeds formation. The result is in agreement with [1]. In addition, the interaction effect between quantity and date of fertilization table (3) showed significant differences on seed number, so $\left(\mathrm{K}_{5} \mathrm{~T}_{2}\right)$ treatment gave maximum seed number (1006) seed.head ${ }^{-1}$, whereas minimum value (392) seed.head ${ }^{-1}$ was recorded with $\left(\mathrm{K}_{\mathbf{0}} \mathrm{T}_{2}\right)$ treatment .

\subsection{Seed weight (gm)}

The data presented in table (2) indicated that potassium application significantly affected the 1000 seed weight. Maximum 1000 Seed weight (77) gm was observed on plants that treated with $\left(\mathbf{K}_{\mathbf{4}}\right)$ treatment, whereas minimum value (48.5) gm was observed on plants that treated with $\left(\mathbf{K}_{\mathbf{3}}\right)$ treatment. $\mathbf{K}_{\mathbf{1}}, \mathbf{K}_{\mathbf{2}}$ and $\mathbf{K}_{\mathbf{5}}$ treatments had non-significant effect on this trait between them. The result is in agreement with [3]. This increasing may be due to the efficiency of plants to translocation of photosynthates towards seeds resulting in more filled seeds (source/ sink efficiency). The interaction effect between quantity and date of fertilization table (3) showed significant differences on 1000 seed weight, so $\left(\mathrm{K}_{0} \mathrm{~T}_{1}\right)$ treatment gave maximum 1000 Seed weight (124.3) gm, whereas minimum value (44.2) gm was recorded with $\left(\mathrm{K}_{0} \mathrm{~T}_{3}\right)$ treatment that on a par with $\left(\mathrm{K}_{1} \mathrm{~T}_{1}\right)$ treatment. 


\section{3 plant yield (gm)}

The data presented in table (2) indicated that potassium application significantly affected the plant yield. Maximum plant yield (67.9) gm was observed on plants that treated with $\left(\mathbf{K}_{4}\right)$ treatment, whereas minimum value (39.6) gm was observed on plants that treated with $\left(\mathbf{K}_{\mathbf{3}}\right)$ treatment. $\mathbf{K}_{\mathbf{0}}, \mathbf{K} \mathbf{1}, \mathbf{K}_{\mathbf{2}}$, and $\mathbf{K}_{\mathbf{5}}$ treatments had non-significant effect on this trait between them. This result is in agreement with [9, 13 and 15] . It is possibly due to the role of fertilization for increasing photosynthesis and translocation of photosynthetic from source to sink. With respect to fertilization dates were affected by plant yield of seeds. The second date $\left(\mathrm{T}_{2}\right)$ gave maximum yield (59.5) gm.plant ${ }^{-1}$, whereas minimum value (39) gm.plant ${ }^{-1}$ was recorded at first date $\left(\mathrm{T}_{1}\right)$. The result is in agreement with [13] due to existence of potassium element in sufficient quantities during growth stages.

\subsection{Seed yield (ton.ha ${ }^{-1}$ )}

The data presented in table (2) indicated that potassium application significantly affected the seed yield. Maximum seed yield (4.36) ton.ha ${ }^{-1}$ was observed on plants that treated with $\left(\mathrm{K}_{1}\right)$ treatment which was superior to all the other treatments, whereas minimum value (2.30) ton.ha ${ }^{-1}$ was observed on plants that treated with control $\left(\mathrm{K}_{\mathbf{5}}\right)$ treatment. The result is in agreement with [9 and 10]. It is possibly due to the role of fertilization for increasing plant yield resulted in increase of seeds yield. Seed yield was affected significantly by fertilization dates. Third date gave maximum seed yield (3.65) ton.ha ${ }^{-1}$ which was superior to the second date (2.60) ton.ha ${ }^{-1}$ This result is in agreement with [9] due to fertilization date was on time and with optimal level during yield formation.

\subsection{Oil content $(\%)$}

The data presented in table (2) indicated that fertilization date significantly affected the oil content. Third date ( $\mathbf{T}_{\mathbf{3}}$ ) gave maximum oil content (51.1)\% which was superior to all the other dates. The result is in agreement with $[9,13]$ the increasing of potassium application at third date with light and temperature as well as role of potassium in structure of fatty acids may be caused more accumulation of oil towards seeds..

\subsection{Oil yield ton.ha ${ }^{-1}$}

The data presented in table (2) indicated that fertilization date significantly affected the oil yield. Third date $\left(\mathbf{T}_{3}\right)$ gave maximum oil yield (1.907) ton.h ${ }^{-1}$ which was superior to all the other dates, whereas minimum value (1.058) ton.ha ${ }^{-1}$ was recorded at second date $\left(T_{2}\right)$. The result is in agreement with [9] due to application date of potassium was sufficient and on time during that stage to increase oil yield.

\subsection{Oleic acid $(\%)$}

The data presented in table (4) indicated that quantity and date of potassium application, and interaction between them had non-significant effect on oleic acid. The result is contradictory to [12].

\subsection{Linoleic acid $(\%)$}

The data presented in table (4) indicated that quantity of potassium application had significant effect on linoleic acid. The treatment $\left(\mathbf{K}_{\mathbf{1}}\right)$ gave maximum percentage of linoleic acid $(0.62) \%$ which was on a par with $\left(\mathrm{K}_{3}\right.$ and $\left.\mathrm{K}_{5}\right)$ treatments, whereas minimum value $(0.36) \%$ was recorded with $\left(\mathbf{K}_{\mathbf{0}}\right)$ treatment. This result is in agreement with $[10,11]$ and contradictory to [12].

\subsection{Palmitic acid (\%)}

The data presented in table (4) indicated that dates of potassium application had significant effect on palmitic acid. First date $\left(\mathbf{T}_{1}\right)$ gave maximum percentage (7.96) \% which was superior to all the other dates, whereas minimum value (4.62)\% was recorded at third date $\left(\mathrm{T}_{3}\right)$. The result is in agreement with [12].

\subsection{Stearic acid $(\%)$}

The data presented in table (4) indicated that quantity and date of potassium application, and interaction between them had non-significant effect on stearic acid. The result is contradictory to that reported by [12] who found that application of potassium reduced stearic acid percentage.

\subsection{Myristic acid (\%)}

The data presented in table (4) indicated that quantity, date of potassium application, and interaction between them had non-significant effect on myristic acid. 


\section{Spring season}

\subsection{Seed Number (seed.head $\left.{ }^{-1}\right)$}

The data presented in table (6) indicated that potassium application significantly affected the seed number.head ${ }^{-1}$. Maximum seed number $(861)$ seed.head ${ }^{-1}$ was observed on plants that treated with $\left(\mathrm{K}_{1}\right)$ treatment which was superior to all the other dates, whereas minimum value (597) seed.head ${ }^{-1}$ was observed on plants that treated with $\left(\mathrm{K}_{4}\right)$ treatment. This result is in agreement with $[9,14]$ may be due to the role of fertilization, environmental conditions and variety during formation stage and completion of flowering buds, so the seed number was increased significantly.

\subsection{Seed weight (gm)}

The data presented in table (6) indicated that potassium application significantly affected the 1000 seed weight. Maximum 1000 seed weight (84.2) gm was observed on plants that treated with $\left(\mathbf{K}_{\mathbf{3}}\right)$ treatment, whereas minimum value (31.4) gm was observed on plants that treated with $\left(\mathbf{K}_{\mathbf{5}}\right)$ treatment. The result is in agreement with [3] This increasing may be due to the efficiency of plants to translocation of photosynthates towards seeds resulting in more filled seeds (source/ sink efficiency)..

\section{3 plant yield (gm)}

The data presented in table (6) indicated that potassium application significantly affected the plant yield. Maximum plant yield (55.9) gm was observed on plants that treated with $\left(\mathbf{K}_{\mathbf{3}}\right)$ treatment, whereas minimum value (26.1) gm was observed on plants that treated with $\left(\mathbf{K}_{\mathbf{5}}\right)$ treatment. The result is in agreement with [9,13 and 15] possibly due to the role of fertilization for increasing photosynthesis and translocation of photosynthetic from source to sink.

\subsection{Seed yield (ton.ha ${ }^{-1}$ )}

The data presented in table (6) indicated that potassium application significantly affected the seed yield. Maximum Seed yield (3.72) ton.ha ${ }^{-1}$ was observed on plants that treated with $\left(\mathrm{K}_{3}\right)$ treatment which was superior to all the other treatments, whereas minimum value (1.74) ton.ha ${ }^{-1}$ was observed on plants that treated with $\left(\mathrm{K}_{5}\right)$ treatment. The result is in agreement with [9 and 13] it is may be due to the role of fertilization for increasing plant yield resulted in increase of seeds yield.

\subsection{Oil content $(\%)$}

The data presented in table (6) indicated that fertilization date significantly affected the oil content. Third date $\left(\mathbf{T}_{\mathbf{3}}\right)$ gave maximum oil content $(16.65) \%$ which was superior to all the other dates whereas minimum value (13.19) \% was observed with first date $\left(\mathbf{T}_{\mathbf{1}}\right)$. The result is in agreement with $[9,13]$ the increasing of potassium application at third date with light and temperature as well as role of potassium in structure of fatty acids may be caused more accumulation of oil towards seeds..

\subsection{Oil yield ton. ha $^{-1}$}

The data presented in table (6) indicated that fertilization date significantly affected the oil yield. Third date $\left(\mathbf{T}_{3}\right)$ gave maximum oil yield $(0.492)$ ton.h ${ }^{-1}$ which was superior to all the other dates, whereas minimum value (0.297) ton.ha ${ }^{-1}$ was recorded at second date $\left(\mathrm{T}_{2}\right)$. The result is in agreement with [9] possibly due to of potassium application was sufficient and on time during that stage to increase oil yield.

\subsection{Oleic acid (\%)}

The data presented in table (8) indicated that quantity and date of potassium application, and interaction between them had non-significant effect on oleic acid. The result is contradictory to [12].

\subsection{Linoleic acid (\%)}

The data presented in table (8) indicated that quantity of potassium application had significant effect on linoleic acid. The treatment $\left(\mathbf{K}_{\mathbf{1}}\right)$ gave maximum percentage of linoleic acid $(0.62) \%$ which was superior to all the other treatments, whereas minimum value $(0.36) \%$ was recorded with $\left(\mathbf{K}_{\mathbf{0}}\right)$ treatment which was on a par with $\left(\mathrm{K}_{2}\right.$ and $\left.\mathrm{K}_{4}\right)$ treatments, The result is in agreement with [10,11].

Also, dates of potassium application had significant effect on linoleic acid. Second date $\left(\mathbf{T}_{2}\right)$ gave maximum percentage $(0.56) \%$ which was superior to all the other dates, whereas minimum value $(0.37) \%$ was recorded at first date $\left(T_{1}\right)$. The result is in agreement with [12]. With respect the interaction between dates and quantities of potassium application had significant effect on linoleic acid table (9). The treatment $\left(\mathbf{K}_{\mathbf{1}} \mathbf{T}_{\mathbf{3}}\right)$ gave maximum percentage of linoleic acid $(0.70) \%$ which was superior to all the other treatments, whereas minimum value $(0.12) \%$ was recorded with $\left(\mathbf{K}_{\mathbf{0}} \mathbf{T}_{\mathbf{1}}\right)$ treatment. 


\subsection{Palmitic acid $(\%)$}

The data presented in table (8) indicated that dates of potassium application had significant effect on palmitic acid. First date $\left(\mathbf{T}_{\mathbf{1}}\right)$ gave maximum percentage (8.90) \% which was superior to all the other dates, whereas minimum value (3.95) \% was recorded at third date $\left(\mathrm{T}_{3}\right)$. The result is in agreement with [12].

With respect the interaction between dates and quantities of potassium application had significant effect on palmitic acid table (9). The treatment $\left(\mathbf{K}_{\mathbf{0}} \mathbf{T}_{\mathbf{1}}\right)$ gave maximum percentage of palmitic acid (9.65) \% which was on a par with $\left(\mathbf{K}_{\mathbf{4}} \mathbf{T}_{\mathbf{1}}\right)$, whereas minimum value (1.90)\% was recorded with $\left(\mathbf{K}_{\mathbf{2}} \mathbf{T}_{\mathbf{3}}\right)$ treatment.

\subsection{Stearic acid (\%)}

The data presented in table (8) indicated that and dates of potassium application, had significant effect on stearic acid. Second date $\left(\mathbf{T}_{2}\right)$ gave maximum percentage $(7.21) \%$ which was superior to all the other dates, whereas minimum value (1.90) \% was recorded at third date $\left(\mathrm{T}_{3}\right)$. This result is in agreement with [12].

\subsection{Myristic acid (\%)}

The data presented in table (9) indicated that the interaction between dates and quantities of potassium application had significant effect on myristic acid. The treatment $\left(\mathbf{K}_{\mathbf{0}} \mathbf{T}_{\mathbf{2}}, \mathbf{K}_{\mathbf{1}} \mathbf{T}_{\mathbf{1}}, \mathbf{K}_{\mathbf{2}} \mathbf{T}_{\mathbf{2}}, \mathbf{K}_{\mathbf{3}} \mathbf{T}_{\mathbf{1}}, \mathbf{K}_{\mathbf{4}} \mathbf{T}_{\mathbf{2}}\right.$ and $\left.\mathbf{K}_{\mathbf{5}} \mathbf{T}_{\mathbf{1}}\right)$ gave maximum percentage of myristic acid $(0.07) \%$, whereas minimum value $(0.02) \%$ was recorded with $\left(\mathbf{K}_{\mathbf{2}} \mathbf{T}_{\mathbf{3}}\right)$ treatment

Table (2) Effect of dates and quantity of potassium application on yield traits during fall season 2011

\begin{tabular}{|c|c|c|c|c|c|c|}
\hline K treatments & $\begin{array}{c}\text { No. seeds } \\
\text { Seed.head }^{-1}\end{array}$ & $\begin{array}{c}\text { 1000-seed } \\
\text { weight } \\
\text { (gm) }\end{array}$ & $\begin{array}{c}\text { Plant yield } \\
\text { (gm) }\end{array}$ & $\begin{array}{c}\text { Total seed } \\
\text { yield } \\
\left(\text { ton.ha }^{-1}\right)\end{array}$ & $\begin{array}{l}\text { Oil content } \\
(\%)\end{array}$ & $\begin{array}{l}\text { Oil yield } \\
\left(\text { ton.ha }^{-1}\right)\end{array}$ \\
\hline K0 & 589 & 75.2 & 43.4 & 2.89 & 47.0 & 1.633 \\
\hline K1 & 861 & 51.1 & 46.4 & 3.09 & 43.2 & 1.569 \\
\hline K2 & 802 & 58.6 & 45.6 & 3.03 & 46.0 & 1.497 \\
\hline K3 & 774 & 48.5 & 39.6 & 2.63 & 42.8 & 1.888 \\
\hline K4 & 853 & 77.0 & 67.9 & 4.52 & 44.0 & 1.178 \\
\hline K5 & 751 & 58.5 & 46.3 & 3.08 & 40.8 & 0.941 \\
\hline $\begin{array}{l}\text { L.S.D } \\
0.05\end{array}$ & 80.58 & 17.87 & 15.87 & 1.057 & N.S. & N.S. \\
\hline T1 & 636 & 64.6 & 39.0 & 2.60 & 40.7 & 1.387 \\
\hline T2 & 867 & 65.5 & 59.5 & 3.96 & 40.1 & 1.058 \\
\hline T3 & 811 & 54.4 & 46.1 & 3.07 & 51.1 & 1.907 \\
\hline L.S.D 0.05 & 56.9 & N.S. & 11.22 & 0.747 & 6.06 & 0.476 \\
\hline
\end{tabular}

Table (3) Effect of interactions between Dates and Potassium Quantities on Yield traits during Fall

\begin{tabular}{|c|c|c|c|c|c|c|c|}
\hline \multirow[t]{2}{*}{ Traits } & \multirow[t]{2}{*}{ Dates } & \multicolumn{6}{|c|}{ Potassium Quantities } \\
\hline & & K0 & Kl & $\mathbf{K} 2$ & K3 & K4 & K5 \\
\hline \multirow{4}{*}{$\begin{array}{l}\text { Number of } \\
\text { Seeds }\end{array}$} & D1 & 392 & 827 & 640 & 674 & 727 & 556 \\
\hline & D2 & 719 & 871 & 393 & 781 & 934 & 1006 \\
\hline & D3 & 657 & 884 & 872 & 866 & 900 & 689 \\
\hline & L.S.D (0.05) & \multicolumn{6}{|c|}{139.4} \\
\hline \multirow{4}{*}{$\begin{array}{c}1000 \\
\text { Seeds Weight } \\
\text { (gm) }\end{array}$} & D1 & 124.3 & 44.2 & 51.3 & 43.2 & 64.5 & 60.3 \\
\hline & D2 & 57.2 & 62.8 & 70.2 & 52.1 & 86.0 & 64.6 \\
\hline & D3 & 44.2 & 46.3 & 54.4 & 50.2 & 80.4 & 50.6 \\
\hline & L.S.D (0.05) & \multicolumn{6}{|c|}{30.95} \\
\hline \multirow{4}{*}{$\begin{array}{l}\text { Seed Yield of } \\
\text { plant (gm) }\end{array}$} & D1 & 48.8 & 43.0 & 26.2 & 29.2 & 51.1 & 35.8 \\
\hline & D2 & 52.7 & 54.8 & 62.7 & 41.0 & 80.3 & 65.5 \\
\hline & D3 & 28.9 & 41.4 & 47.8 & 48.5 & 72.4 & 37.6 \\
\hline & L.S.D (0.05) & \multicolumn{6}{|c|}{ N.S. } \\
\hline \multirow{4}{*}{$\begin{array}{c}\text { Total seed } \\
\text { Yield (ton.ha-1) }\end{array}$} & D1 & 3.25 & 2.86 & 1.74 & 1.94 & 3.40 & 2.38 \\
\hline & D2 & 3.51 & 3.65 & 4.17 & 2.73 & 5.35 & 4.36 \\
\hline & D3 & 1.92 & 2.75 & 3.18 & 3.23 & 4.82 & 2.50 \\
\hline & L.S.D (0.05) & \multicolumn{6}{|c|}{ N.S. } \\
\hline \multirow{4}{*}{ Oil percent $\%$} & D1 & 40.4 & 42.8 & 39.7 & 42.6 & 37.7 & 40.6 \\
\hline & D2 & 38.9 & 43.5 & 38.3 & 42.8 & 36.3 & 40.8 \\
\hline & D3 & 61.5 & 43.4 & 60.0 & 42.9 & 58.0 & 40.8 \\
\hline & L.S.D (0.05) & \multicolumn{6}{|c|}{ N.S. } \\
\hline \multirow{4}{*}{ Oil yield } & D1 & 1.090 & 1.669 & 1.264 & 1.336 & 0.715 & 1.249 \\
\hline & D2 & 1.228 & 1.344 & 1.000 & 1.230 & 0.773 & 0.774 \\
\hline & D3 & 2.580 & 1.695 & 2.225 & 2.098 & 2.045 & 0.799 \\
\hline & L.S.D (0.05) & \multicolumn{6}{|c|}{ N.S. } \\
\hline
\end{tabular}


Effect of Date and Quantity of Potassium Fertilizer Application on Growth, Yield and Oil Quality of

Table (4) Effect of Dates and Quantity of Potassium Application on Fatty acids (\%) during Fall Season 2011

\begin{tabular}{c|c|c|c|c|c}
\hline \multirow{2}{*}{ K treatments } & \multicolumn{5}{c}{ Fatty acids contents (\%) } \\
\cline { 2 - 6 } & Oleic (\%) & Linoleic (\%) & Palmitic (\%) & Stearic (\%) & Myristic (\%) \\
\hline K0 & 0.026 & 0.36 & 6.68 & 5.00 & 0.04 \\
\hline K1 & 0.023 & 0.62 & 6.37 & 6.73 & 0.06 \\
\hline K2 & 0.018 & 0.45 & 5.83 & 4.83 & 0.05 \\
\hline K3 & 0.023 & 0.62 & 6.37 & 6.73 & 0.06 \\
\hline K4 & 0.023 & 0.43 & 5.87 & 5.13 & 0.05 \\
\hline L.S.D 0.05 & 0.014 & 0.62 & 5.83 & 5.83 & 0.06 \\
\hline \multicolumn{7}{|c|}{ N.S. } & $\mathbf{0 . 2 0 3}$ & N.S. & N.S. & N.S. \\
\hline T2 & 0.034 & 0.43 & 7.96 & 6.47 & 0.05 \\
\hline T3 & 0.021 & 0.59 & 5.89 & 6.17 & 0.06 \\
\hline L.S.D 0.05 & 0.009 & 0.53 & 4.62 & 4.47 & 0.05 \\
\hline
\end{tabular}

Table (5) Effect of interactions between Dates and Potassium Quantities on Fatty Acids content (\%) during fall season 2011

\begin{tabular}{|c|c|c|c|c|c|c|c|}
\hline \multirow{2}{*}{ Fatty acids } & \multirow{2}{*}{ Dates } & \multicolumn{6}{|c|}{ Potassium Quantities } \\
\hline & & K0 & Kl & K2 & K3 & K4 & K5 \\
\hline \multirow{4}{*}{ Oleic (\%) } & Dl & 0.030 & 0.045 & 0.031 & 0.045 & 0.031 & 0.020 \\
\hline & D2 & 0.045 & 0.019 & 0.004 & 0.019 & 0.020 & 0.019 \\
\hline & D3 & 0.002 & 0.005 & 0.018 & 0.005 & 0.018 & 0.004 \\
\hline & L.S.D (0.05) & \multicolumn{6}{|c|}{ N.S. } \\
\hline \multirow{4}{*}{ Lingleic (\%) } & Dl & 0.12 & 0.63 & 0.28 & 0.63 & 0.28 & 0.63 \\
\hline & D2 & 0.63 & 0.53 & 0.60 & 0.53 & 0.63 & 0.63 \\
\hline & D3 & 0.33 & 0.70 & 0.47 & 0.70 & 0.37 & 0.60 \\
\hline & L.S.D (0.05) & \multicolumn{6}{|c|}{ N.S. } \\
\hline \multirow{4}{*}{ Palmitic (\%) } & Dl & 9.65 & 8.17 & 7.95 & 8.17 & 7.28 & 6.57 \\
\hline & D2 & 8.17 & 5.17 & 4.37 & 5.17 & 6.57 & 5.90 \\
\hline & D3 & 2.24 & 5.77 & 5.17 & 5.77 & 3.77 & 5.03 \\
\hline & L.S.D (0.05) & \multicolumn{6}{|c|}{ N.S. } \\
\hline \multirow{4}{*}{ Stearic (\%) } & Dl & 3.78 & 9.48 & 4.88 & 9.48 & 4.42 & 6.80 \\
\hline & D2 & 9.48 & 5.27 & 3.90 & 5.27 & 6.80 & 6.33 \\
\hline & D3 & 1.73 & 5.43 & 5.70 & 5.43 & 4.17 & 4.37 \\
\hline & L.S.D (0.05) & \multicolumn{6}{|c|}{ N.S. } \\
\hline \multirow{4}{*}{ Myristic (\%) } & Dl & 0.03 & 0.07 & 0.05 & 0.07 & 0.04 & 0.06 \\
\hline & D2 & 0.07 & 0.05 & 0.05 & 0.05 & 0.06 & 0.06 \\
\hline & D3 & 0.03 & 0.06 & 0.05 & 0.06 & 0.03 & 0.06 \\
\hline & L.S.D (0.05) & \multicolumn{6}{|c|}{ N.S. } \\
\hline
\end{tabular}

Table (6) Effect of Dates and Quantity of Potassium Application on Yield traits during Spring Season

\begin{tabular}{|c|c|c|c|c|c|c|}
\hline \multicolumn{7}{|c|}{2012} \\
\hline $\mathrm{K}$ treatments & $\begin{array}{c}\text { No. seeds } \\
\text { Seed.head }^{-1}\end{array}$ & $\begin{array}{c}\text { 1000-seed } \\
\text { weight }(\mathrm{gm})\end{array}$ & $\begin{array}{c}\begin{array}{c}\text { Plant yield } \\
\text { (gm) }\end{array} \\
\text { (a) }\end{array}$ & $\begin{array}{c}\text { Total seed yield } \\
\left(\text { ton.ha }^{-1}\right)\end{array}$ & $\begin{array}{c}\text { Oil content } \\
(\%)\end{array}$ & $\begin{array}{c}\text { Oil yield } \\
\left(\text { ton.ha }^{-1}\right)\end{array}$ \\
\hline K0 & 709 & 37.0 & 39.6 & 2.64 & 15.18 & 0.424 \\
\hline K1 & 860 & 31.8 & 46.0 & 3.07 & 14.52 & 0.446 \\
\hline K2 & 668 & 79.2 & 38.1 & 2.54 & 13.98 & 0.365 \\
\hline $\mathbf{K 3}$ & 821 & 84.2 & 55.9 & 3.72 & 12.84 & 0.483 \\
\hline K4 & 597 & 44.6 & 30.2 & 2.01 & 16.12 & 0.332 \\
\hline K5 & 716 & 31.4 & 26.1 & 1.74 & 14.50 & 0.253 \\
\hline L.S.D 0.05 & 121.6 & 24.34 & 15.42 & 1.028 & N.S. & N.S. \\
\hline \multicolumn{7}{|c|}{ Dates } \\
\hline T1 & 721 & 60.5 & 41.8 & 2.78 & 13.19 & 0.362 \\
\hline T2 & 685 & 41.9 & 32.1 & 2.14 & 13.73 & 0.297 \\
\hline T3 & 779 & 51.7 & 44.1 & 2.94 & 16.65 & 0.492 \\
\hline $\begin{array}{l}\text { L.S.D } 0.05 \\
\end{array}$ & N.S. & N.S. & N.S. & N.S. & 1.772 & 0.1255 \\
\hline
\end{tabular}


Effect of Date and Quantity of Potassium Fertilizer Application on Growth, Yield and Oil Quality of

Table (7) Effect of interactions between Dates and Potassium Quantities on Yield traits during Spring Season.

\begin{tabular}{|c|c|c|c|c|c|c|c|}
\hline \multirow[t]{2}{*}{ Traits } & \multirow[t]{2}{*}{ Dates } & \multicolumn{6}{|c|}{ Potassium Quantities } \\
\hline & & Ko & K1 & K2 & K3 & K4 & K5 \\
\hline \multirow{4}{*}{ Number of Seeds } & \multirow{3}{*}{$\begin{array}{l}\text { D1 } \\
\text { D2 } \\
\text { D3 }\end{array}$} & 636 & 870 & 586 & 900 & 513 & 823 \\
\hline & & 690 & 817 & 589 & 783 & 553 & 678 \\
\hline & & 801 & 894 & 830 & 778 & 727 & 647 \\
\hline & L.S.D (0.05) & \multicolumn{6}{|c|}{ N.S. } \\
\hline \multirow{4}{*}{$\begin{array}{c}1000 \\
\text { Seeds Weight } \\
\text { (gm) }\end{array}$} & \multirow{3}{*}{$\begin{array}{l}\text { D1 } \\
\text { D2 } \\
\text { D3 }\end{array}$} & 54.8 & 29.5 & 95.0 & 97.2 & 46.3 & 40.0 \\
\hline & & 30.2 & 30.4 & 68.1 & 62.0 & 33.7 & 27.0 \\
\hline & & 25.9 & 35.5 & 74.4 & 93.3 & 53.9 & 27.3 \\
\hline & L.S.D (0.05) & \multicolumn{6}{|c|}{ N.S. } \\
\hline \multirow{4}{*}{$\begin{array}{l}\text { Seed Yield of } \\
\text { plant (gm) }\end{array}$} & \multirow{3}{*}{$\begin{array}{l}\text { D1 } \\
\text { D2 } \\
\text { D3 }\end{array}$} & 34.7 & 48.7 & 38.5 & 72.9 & 29.7 & 26.1 \\
\hline & & 34.7 & 42.7 & 28.6 & 33.4 & 29.0 & 24.0 \\
\hline & & 49.3 & 46.6 & 47.2 & 61.3 & 31.9 & 28.2 \\
\hline & L.S.D (0.05) & \multicolumn{6}{|c|}{ N.S. } \\
\hline \multirow{4}{*}{$\begin{array}{l}\text { Total seed Yield } \\
\quad\left(\text { ton.ha }^{-1}\right)\end{array}$} & \multirow{3}{*}{$\begin{array}{l}\text { D1 } \\
\text { D2 } \\
\text { D3 }\end{array}$} & 2.31 & 3.25 & 2.56 & 4.86 & 1.98 & 1.74 \\
\hline & & 2.32 & 2.84 & 1.91 & 2.23 & 1.93 & 1.60 \\
\hline & & 3.29 & 3.10 & 3.15 & 4.09 & 2.13 & 1.88 \\
\hline & L.S.D (0.05) & \multicolumn{6}{|c|}{ N.S. } \\
\hline \multirow{4}{*}{ Oil percent $\%$} & \multirow{3}{*}{$\begin{array}{l}\text { D1 } \\
\text { D2 } \\
\text { D3 }\end{array}$} & 11.46 & 11.70 & 13.46 & 12.92 & 15.46 & 14.14 \\
\hline & & 13.98 & 15.42 & 11.13 & 13.16 & 13.64 & $\overline{14.90}$ \\
\hline & & 20.10 & 16.46 & 17.18 & 12.46 & 19.25 & 14.46 \\
\hline & L.S.D (0.05) & \multicolumn{6}{|c|}{ N.S. } \\
\hline \multirow{4}{*}{ Oil yield } & \multirow{3}{*}{$\begin{array}{l}\text { D1 } \\
\text { D2 } \\
\text { D3 }\end{array}$} & 0.262 & 0.383 & 0.342 & 0.628 & 0.309 & 0.246 \\
\hline & & 0.332 & 0.443 & 0.214 & 0.292 & 0.263 & 0.240 \\
\hline & & 0.676 & 0.446 & 0.540 & 0.528 & 0.425 & 0.272 \\
\hline & L.S.D (0.05) & \multicolumn{6}{|c|}{ N.S. } \\
\hline
\end{tabular}

Table (8) Effect of Dates and Quantity of Potassium Application on Fatty acids (\%) during Spring Season 2012

\begin{tabular}{|c|c|c|c|c|c}
\hline \multirow{2}{*}{ K treatments } & \multicolumn{5}{|c}{ Fatty acids contents (\%) } \\
\cline { 2 - 6 } & Oleic (\%) & Linoleic (\%) & Palmitic (\%) & Stearic (\%) & $\begin{array}{c}\text { Myristic } \\
\text { (\%) }\end{array}$ \\
\hline K0 & 0.025 & 0.36 & 6.68 & 5.00 & 0.04 \\
\hline K1 & 0.028 & 0.62 & 6.34 & 6.61 & 0.06 \\
\hline K2 & 0.050 & 0.36 & 6.46 & 4.78 & 0.04 \\
\hline K3 & 0.023 & 0.60 & 6.37 & 6.73 & 0.06 \\
\hline K4 & 0.026 & 0.36 & 6.68 & 5.00 & 0.04 \\
\hline K5 & 0.024 & 0.60 & 6.14 & 6.61 & 0.06 \\
\hline L.S.D 0.05 & N.S. & $\mathbf{0 . 1 7 5}$ & N.S. & N.S. & N.S. \\
\hline \multicolumn{6}{|c|}{ Dates } \\
\hline T1 & 0.037 & 0.37 & 8.90 & 6.57 & 0.05 \\
\hline T2 & 0.034 & 0.56 & 6.50 & 7.21 & 0.06 \\
\hline T3 & 0.016 & 0.52 & 3.95 & 3.58 & 0.04 \\
\hline L.S.D 0.05 & N.S. & $\mathbf{0 . 1 2 3}$ & $\mathbf{1 . 1 6 1}$ & $\mathbf{2 . 4 5}$ & N.S. \\
\hline
\end{tabular}

Table (9) Effect of interactions between Dates and Potassium Quantities on Fatty Acids (\%) during Spring season 2012

\begin{tabular}{|c|c|c|c|c|c|c|c|}
\hline \multirow{2}{*}{ Fatty acids } & \multirow{2}{*}{ Dates } & \multicolumn{6}{|c|}{ Potassium Quantities } \\
\hline & & K0 & K1 & K2 & K3 & K4 & K5 \\
\hline \multirow{4}{*}{ Oleic (\%) } & \multirow{3}{*}{$\begin{array}{l}\text { D1 } \\
\text { D2 } \\
\text { D3 }\end{array}$} & 0.030 & 0.045 & 0.030 & 0.045 & 0.030 & 0.045 \\
\hline & & 0.042 & 0.026 & 0.052 & 0.019 & 0.045 & 0.022 \\
\hline & & 0.002 & 0.015 & 0.069 & 0.005 & 0.002 & 0.005 \\
\hline & L.S.D (0.05) & \multicolumn{6}{|c|}{ N.S. } \\
\hline \multirow{3}{*}{ Linoleic (\%) } & \multirow{3}{*}{$\begin{array}{l}\text { D1 } \\
\text { D2 } \\
\text { D3 }\end{array}$} & 0.12 & 0.62 & 0.12 & 0.62 & 0.12 & 0.62 \\
\hline & & 0.63 & 0.53 & 0.63 & 0.47 & 0.63 & 0.47 \\
\hline & & 0.33 & 0.70 & 0.33 & 0.70 & 0.33 & 0.70 \\
\hline
\end{tabular}




\begin{tabular}{|c|c|c|c|c|c|c|c|}
\hline & L.S.D (0.05) & \multicolumn{6}{|c|}{0.302} \\
\hline \multirow{4}{*}{ Palmitic (\%) } & \multirow{3}{*}{$\begin{array}{l}\text { D1 } \\
\text { D2 } \\
\text { D3 }\end{array}$} & 9.65 & 8.10 & 9.65 & 8.17 & 9.65 & 8.17 \\
\hline & & 8.17 & 5.17 & 7.83 & 5.17 & 8.17 & 4.50 \\
\hline & & 2.24 & 5.77 & 1.90 & 5.77 & 2.24 & 5.77 \\
\hline & L.S.D (0.05) & \multicolumn{6}{|c|}{2.845} \\
\hline \multirow{4}{*}{ Stearic (\%) } & \multirow{3}{*}{$\begin{array}{l}\text { D1 } \\
\text { D2 } \\
\text { D3 }\end{array}$} & 3.78 & 9.48 & 3.78 & 9.48 & 3.78 & 9.14 \\
\hline & & 9.48 & 4.93 & 8.81 & 5.27 & 9.48 & 5.27 \\
\hline & & 1.73 & 5.43 & 1.73 & 5.43 & 1.73 & 5.43 \\
\hline & L.S.D (0.05) & \multicolumn{6}{|c|}{ N.S. } \\
\hline \multirow{4}{*}{ Myristic (\%) } & \multirow{3}{*}{$\begin{array}{l}\text { D1 } \\
\text { D2 } \\
\text { D3 }\end{array}$} & 0.03 & 0.07 & 0.03 & 0.07 & 0.03 & 0.07 \\
\hline & & 0.07 & 0.05 & 0.07 & 0.05 & 0.07 & 0.05 \\
\hline & & 0.03 & 0.06 & 0.02 & 0.06 & 0.03 & 0.06 \\
\hline & L.S.D (0.05) & \multicolumn{6}{|c|}{0.040} \\
\hline
\end{tabular}

\section{Conclusion}

Results indicated that application of potassium at second date $\mathbf{T}_{\mathbf{2}}$ increased Seed number, 1000 seed weight, Plant yield and total seed yield, whereas Oil content and yield were increased with date of potassium application especially at third date $\mathbf{T}_{\mathbf{3}}$. According to these results, it may recommended that fertilization of sunflower crop with $\mathbf{K}_{\mathbf{3}}$ treatment at third date $\mathbf{T}_{\mathbf{3}}$ for obtaining higher seed yield during both seasons. Also fertilization of potassium at third date when the aim is increasing content and yield of oil.

\section{Acknowledgements}

\section{References}

[1] Murphy, W.M. 1978. Effects of planting date on seed oil and forage yield of irrigated sunflower.

[2] Syed, A. S., M. Shahid, A. Jan and S. Noor-ud-din 2000. Effect of various Levels of Nitrogen, Phosphorus and Potassium (NPK) on growth, Yield and yield components of Sunflower. Pakistan Jornal of Biological Sciences. 2000, Vol. 3, (2) pp:338-339.

[3] Abdel-Motagally F. M. F. and E. A. Osman 2010. Effect of Nitrogen and Potassium Fertilization combination on productivity of two Sunflower cultivars under east of El-ewinatecondition. American - Eurasian Journal Agric. \& Environ. Sci.8 (4). 2010, pp. 397 401

[4] Chaudhry, A. U., and M. Mushtaq. 1999. Optimization of potassium in Sunflower. Pakistan Jornal of Biological Sciences. 2 (3), pp. 887-888.

[5] Alzobay, M.A. S. and J. H. Hamza. 2003. Effect levels of phosphorous and potash fertilizer on growth and yield sunflower. Morphological and Quality Traits.Iraqi journal of Agricultural Sciences.Pp 111-120,Volume 6 (34).

[6] Abodhahy,Y.M. and M.A. Alyones.1988. Plant Nutrition guide. Ministry of higher education and scientific research. Baghdad university.

[7] Page, A. L. and et.al. 1982. Methods of soil analysis . Part (2) Agronomy No. 9. Madison . USA : s.n., 1982.

[8] Alaloosy,Y.A.M. 2002. Effect of interaction between application of K , N and P fertilizer on growth and yield of sunflower. Iraqi journal of Agricultural Sciences, Vol. 3(33).

[9] Lahmood, A.M. 1999. Effect of different dates of foliar fertilization on increasing percent of fertilization and yield seeds of two cultivars of sunflower. Technical college/Almusaib.Al-qadesyah journal.2006,Vol. 11(1), Pp 1-13.

[10] Salama, A. (1987). Yield and oil quality of sunflowers as affected by fertilizers and growth regulators. (36), pp. 191-202.

[11] Mekki, B. (1999). Yield, oil and fatty acids content as affected by water deficit and potassium fertilization in two sunflower cultivars. Egypt. J. Agron. (21), pp. 67-85.

[12] Ahmad, R.,M. Saeed, E. Ullah and T. Mahmood 1999. Effect of Potassium on protein,Oil and Fatty acids contents in Two Autumn planted Sunflower Hybrids. Intenational Journal of Agriculture \& Biology. 1999, Vol. 1, 4, pp. 325-327.

[13] Adnan, Y.Y.2011. Effect of foliar fertilization ALGATON on growth traits, seed and oil yield of sunflower Helianthus annuus L. Iraq flower c.v. Tekreet journal of Agricultural Sciences, vol. 11(3),Pp 102-109.

[14] Aldolayme, H.Y. and Y.A. Alaloosy.2001. Effect of compound fertilizer (N, P, K) using foliar and soil application on yield and yield components of sunflower plant. Iraqi journal of Agricultural Sciences, Vol.32(4), Pp 55-58.

[15] Grove, J. H. and M. E. Sumner 1982. Yield and leaf composition of sunflower in relation to N, P, K, and lime treatments. Jornal Nutrient Cycling in Agroecosystems. 1982, Vol. 3,(4), pp. 367-378. 